\title{
Satisfaction and discontent of Polish patients with biological therapy of rheumatic diseases: results of a multi-center questionnaire study
}

\author{
Anna Kotulska ${ }^{1}$, Eugeniusz J. Kucharz ${ }^{1}$, Piotr Wiland ${ }^{2}$, Marzena Olesińska ${ }^{3}$, Anna Felis-Giemza ${ }^{3}$, \\ Magdalena Kopeć-Mędrek ${ }^{1}$, Aleksandra Zoń-Giebel ${ }^{4}$, Wojciech Romanowski ${ }^{5}$, \\ Lucyna Szymczak-Bartz ${ }^{5}$, Małgorzata Tłustochowicz ${ }^{6}$, Jolanta Lewandowicz \\ Joanna Kowalska-Majka ${ }^{7}$, Jolanta Bucka ${ }^{8}$, Maria Majdan ${ }^{9}$, Zofia Kiełbik ${ }^{9}$, Mariusz Korkosz ${ }^{10}$, \\ Aneta Bielińska ${ }^{10}$, Piotr Leszczyński ${ }^{11}$, Katarzyna Pawlak-Buś ${ }^{11}$, Mariusz J. Puszczewicz ${ }^{12}$, \\ Dominik Majewski ${ }^{12}$, Katarzyna Smolik ${ }^{13}$, Teresa Migas-Kukla ${ }^{13}$, Małgorzata Sochocka-Bykowska ${ }^{14}$, \\ Maria Szarecka ${ }^{14}$, Bernadeta Luberda ${ }^{14}$, Małgorzata Falenta-Hitnarowicz ${ }^{15}$, \\ Jadwiga Świkszcz-Gniadek ${ }^{16}$, Wanda Lepiarz-Rusek ${ }^{17}$, Grzegorz Rozwadowski ${ }^{18}$, Barbara Chara ${ }^{19}$, \\ Jerzy Zajdel ${ }^{20}$, Zbigniew Zdrojewski ${ }^{21}$, Maria Maciejowska-Roge ${ }^{22}$, Irena Rosmus-Kuczia ${ }^{23}$

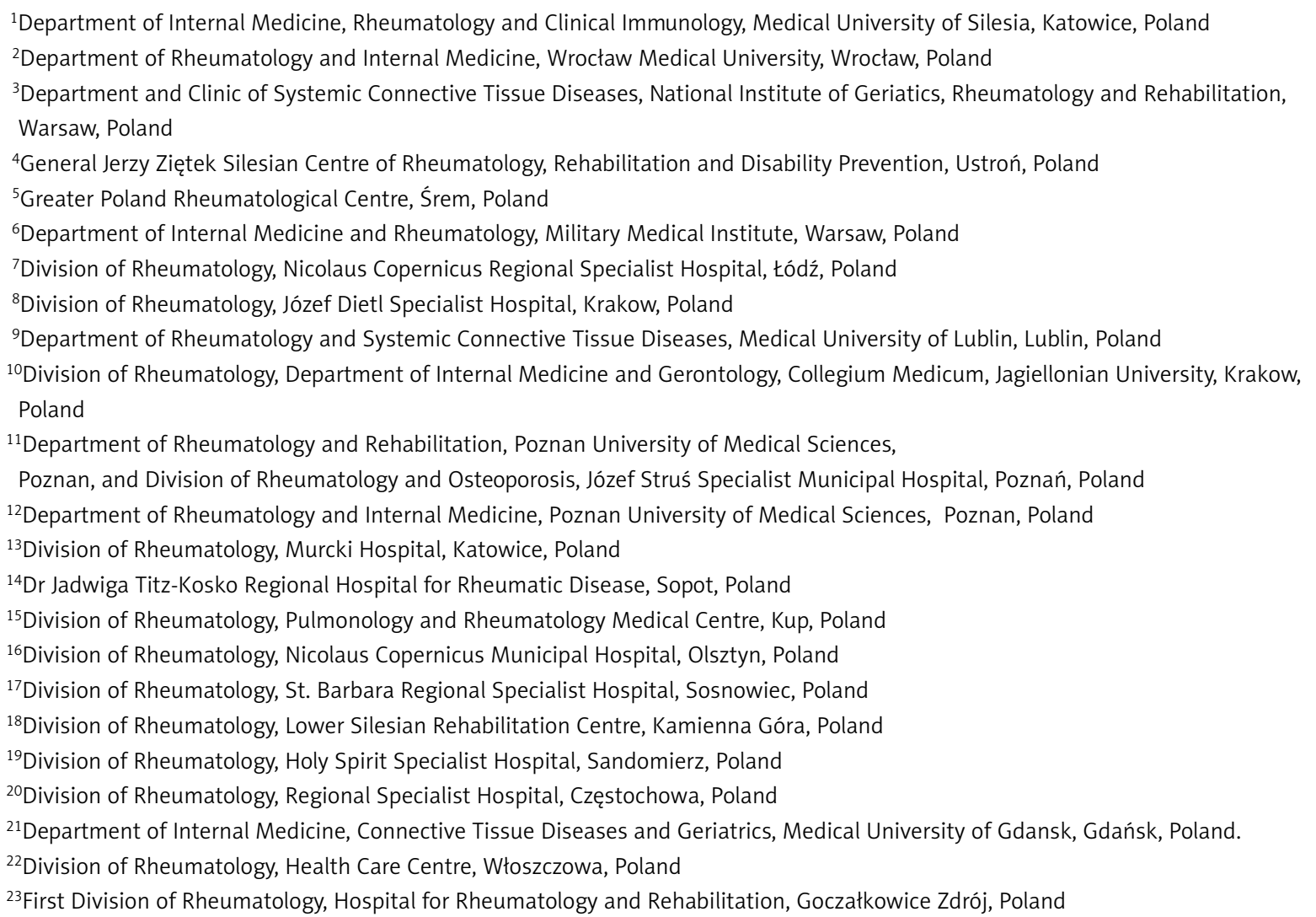

Address for correspondence:

Eugeniusz J. Kucharz, Department of Internal Medicine, Rheumatology and Clinical Immunology, Medical University of Silesia, 45/47 Ziołowa St., 40-635 Katowice, Poland; e-mail: ejkucharz@poczta.onet.pl

Submitted: 2.05.2018; Accepted: 11.06.2018 


\begin{abstract}
Objectives: Biologics are medications widely applied in the management of inflammatory rheumatic diseases. The drugs were found to be effective but their application is associated with some disadvantages. Medication with biologics is relatively expensive, and in Poland, it is carried out in specialized centers. The study was designed to evaluate various aspects of satisfaction and dissatisfaction of Polish patients treated with biologics.

Material and methods: An anonymous questionnaire was distributed in 23 Polish rheumatological centers involved in the treatment; 1212 returned questionnaires were used for analysis. Responses were received from 606 patients with rheumatoid arthritis, 427 with ankylosing spondylitis, 117 psoriatic arthritis, and 62 adult patients with juvenile idiopathic arthritis (in whom administration of the drugs had been introduced before they were 18 years old). The investigated group constituted about one-fifth of all rheumatic patients on biologics in Poland.

Results: A beneficial or very beneficial influence of the medication on the state of physical health was found mostly in patients with rheumatoid arthritis (51.3 and 30.5\%) and ankylosing spondylitis (51.0 and $36.8 \%$ ). Family life was improved by the treatment especially in patients with ankylosing spondylitis (40.7 and $35.6 \%$ beneficial and very beneficial, respectively), sleep quality and sexual life mostly in those with ankylosing spondylitis (beneficial/very beneficial influence 41.5/38.4, and $38.7 / 23.9$, respectively). There was a rather small influence of biological treatment on the financial situation of the patients. In general, satisfaction with the treatment was evaluated as positive or very positive in $88 \%$ of all investigated patients.

In a significant part of the patients, transportation to the medical center was considered as a disadvantage of the treatment. About one-third of the patients considered laboratory and imaging tests to be done before initiation of the medication as a difficulty, and for about $40 \%$ waiting time for qualification for the medication was a significant disadvantage. The route of drug administration was without importance for $4 / 5$ of the patients.

Conclusions: Summing up, the results were similar in the patients suffering from various diseases although those with psoriatic arthritis felt the highest satisfaction (possibly due to the positive aesthetic effect), and those with ankylosing spondylitis had significant improvement in sexual life (probably due to younger age). Relatively low satisfaction was found in patients with juvenile idiopathic arthritis. There was a small influence of medication on financial status of the patients. Application of biologics has few disadvantages and most of them are associated with the organization of health services (waiting time for the tests, transportation to the medical centers).
\end{abstract}

Key words: rheumatoid arthritis, ankylosing spondylitis, psoriatic arthritis, juvenile idiopathic arthritis, biological therapy.

\section{Introduction}

Management of inflammatory rheumatic disease has been marked by significant advances in the last two decades with introduction of biological therapies [1-4]. Administration of these medications has resulted in an undisputable improvement in symptoms and signs of the disease as well as function and quality of life in a number of patients with rheumatoid arthritis, ankylosing spondylitis, juvenile idiopathic arthritis or psoriatic arthritis. Pathogenesis of the diseases remains only partially elucidated. Inflammatory mechanisms are closely associated with various immune disturbances $[5,6]$, some of which affect such phenomena as control of apoptosis [7] or angiogenesis [8].

Clinical aspects of the biological therapy have been extensively investigated both in well-controlled clinical trials and real-life studies, including data from registers [2, 3, 9].
Another aspect, patient satisfaction or disadvantages of the therapy, is relatively little explored in published reports. Clinical aspects such as efficacy or safety are generally universal and apply to all similar populations of patients. On the other hand, satisfaction and so-called social aspects of medication are mostly local and related to geographical location, cultural traditions and the economic situation of the country, as well as to some other factors [5].

The present study was designed to evaluate patient satisfaction with biological therapy and disadvantages associated with this method of treatment. The term "satisfaction" is not precisely defined. In general, it refers to a pleasant or happy feeling about something that was done or happened or was needed. In this meaning, satisfaction with the medication is an outcome of the therapy that is significantly positively received by the patient. In 
the present study, we used a questionnaire to evaluate different aspects of satisfaction, such as influence of medication on physical state, emotional state, financial situation of the patient, his/her professional performance, family and sexual life as well as leisure time.

Biological therapy is Poland is administered in selected centers and medication can be associated with some disadvantages as well. Factors that can create discontent in the patients were also included in the questionnaire. The study was conducted by the Polish Society for Rheumatology within its Section of Recommendations and Clinical Initiatives.

\section{Material and methods}

The questionnaire was prepared by the authors of the study, and was provided to patients receiving biological medication of rheumatic diseases. The response was voluntary and anonymous. We received 1239 questionnaires from 23 centers administrating the medication. Eight questionnaires were incompletely fulfilled and were rejected. The final analysis was based on 1212 questionnaires obtained from patients treated with biological drugs due to rheumatoid arthritis, ankylosing spondylitis, psoriatic arthritis and juvenile idiopathic arthritis. The remaining 19 patients were receiving biological therapy due to other diseases (e.g. vasculitis). The last group was not included in the study because it consisted of patients suffering from various diseases and some of the patients were receiving the medication for an unapproved indication. The investigated questionnaires were obtained from about $20 \%$ of all patients with rheumatic diseases receiving biological medication in Poland. All included patients were receiving the biological therapy within the reimbursement program called the medicinal program of the National Health Fund - the state insurance company.

\section{Results}

\section{Characteristics of patients}

There were 714 (58.9\%) female patients and 498 (41.1\%) male patients. All patients were 18 or more years old. Patients with juvenile idiopathic arthritis included in

Table I. Demographic characteristics of investigated subjects

\begin{tabular}{|c|c|c|c|c|c|}
\hline Feature & All (\%) & $\begin{array}{l}\text { Rheumatoid } \\
\text { arthritis (\%) }\end{array}$ & $\begin{array}{c}\text { Ankylosing } \\
\text { spondylitis (\%) }\end{array}$ & Psoriatic arthritis (\%) & $\begin{array}{c}\text { Juvenile idiopathic } \\
\text { arthritis (\%) }\end{array}$ \\
\hline Female & 714 (58.9) & 485 (67.9) & $130(18.2)$ & $52(7.3)$ & $47(6.6)$ \\
\hline Male & $498(41.1)$ & $121(24.3)$ & 297 (59.6) & $297(13.1)$ & $15(3.0)$ \\
\hline All & $1212(100.0)$ & $\begin{array}{l}606(F: M= \\
80.0 / 20.0)^{\star}\end{array}$ & $\begin{array}{l}427(F: M= \\
30.4 / 69.6)^{\star}\end{array}$ & $117(F: M=44.4 / 55.6)^{*}$ & $\begin{array}{l}62(F: M= \\
75.8 / 24.2)^{\star}\end{array}$ \\
\hline \multicolumn{6}{|l|}{ Age (years) } \\
\hline $18-29$ & $183(15.2)$ & $51(8.4)$ & $65(15.2)$ & $14(12.0)$ & $53(85.5)$ \\
\hline $30-39$ & $255(21.0)$ & $73(12.0)$ & $153(35.8)$ & $24(20.5)$ & $5(.8 .1)$ \\
\hline $40-49$ & $239(19.7)$ & $111(18.3)$ & $94(22.0)$ & $31(26.5)$ & $3(4.8)$ \\
\hline $50-59$ & $332(27.4)$ & $207(34.2)$ & $87(20.4)$ & $38(32.5)$ & $0(0.0)$ \\
\hline 60 and more & $203(16.7)$ & $164(27.1)$ & $28(6.6)$ & $10(8.5)$ & $1(1.6)$ \\
\hline \multicolumn{6}{|l|}{ Educational level } \\
\hline Elementary & $38(3.1)$ & $25(4.1)$ & $8(1.9)$ & $4(3.4)$ & $1(1.6)$ \\
\hline Vocational & $242(20.0)$ & $136(22.4)$ & $80(18.7)$ & $20(17.1)$ & $6(9.7)$ \\
\hline High school & $345(28.5)$ & $182(30.0)$ & $106(24.8)$ & $35(29.9)$ & $22(35.5)$ \\
\hline College level & $146(12.0)$ & $76(12.5)$ & $45(10.6)$ & $10(8.5)$ & $15(24.2)$ \\
\hline $\begin{array}{l}\text { University (not } \\
\text { completed) }\end{array}$ & $88(7.3)$ & $41(6.8)$ & $30(7.0)$ & $10(8.5)$ & $7(11.3)$ \\
\hline $\begin{array}{l}\text { University } \\
\text { (graduated) }\end{array}$ & $353(29.1)$ & $146(24.2)$ & $158(37.0)$ & $38(32.6)$ & $11(17.7)$ \\
\hline Unmarried & $266(22.0)$ & $83(13.8)$ & $103(24.1)$ & $28(23.9)$ & $52(83.9)$ \\
\hline Married & 708 (58.4) & 339 (55.9) & $289(67.7)$ & $71(60.7)$ & $9(14.5)$ \\
\hline Divorced & $175(14.4)$ & $136(22.4)$ & $27(6.3)$ & $11(9.4)$ & $1(1.6)$ \\
\hline Widow/widower & $63(5.2)$ & $48(7.9)$ & $8(1.9)$ & $7(6.0)$ & 0 \\
\hline
\end{tabular}

*female to male ratio within the group of one disease 
Table II. Place of residence of patients

\begin{tabular}{|lccccc|}
\hline Place of residence & All (\%) & $\begin{array}{c}\text { Rheumatoid } \\
\text { arthritis (\%) }\end{array}$ & $\begin{array}{c}\text { Ankylosing } \\
\text { spondylitis (\%) }\end{array}$ & $\begin{array}{c}\text { Psoriatic arthritis } \\
(\%)\end{array}$ & $\begin{array}{c}\text { Juvenile idiopathic } \\
\text { arthritis (\%) }\end{array}$ \\
\hline Village & $321(26.6)$ & $157(25.9)$ & $112(26.2)$ & $36(30.8)$ & $16(25.8)$ \\
\hline $\begin{array}{l}\text { Town < 30,000 } \\
\text { inhabitants }\end{array}$ & $198(16.4)$ & $99(16.3)$ & $67(15.7)$ & $23(19.6)$ & $9(14.5)$ \\
\hline $\begin{array}{l}\text { Town 30,000-100,000 } \\
\text { inhabitants }\end{array}$ & $268(22.2)$ & $140(23.1)$ & $94(22.0)$ & $24(20.5)$ & $10(16.1)$ \\
\hline $\begin{array}{l}\text { Town > 100,000 } \\
\text { inhabitants }\end{array}$ & $425(34.8)$ & $210(34.7)$ & $154(36.1)$ & $34(29.1)$ & $27(43.6)$ \\
\hline
\end{tabular}

the study had been diagnosed a few years earlier when they had been children but the present study included only those of them who were adults and continued medication with biological drugs when they responded to the questionnaire. Half of the investigated patients (50\%) suffered from rheumatoid arthritis, 35\% were being treated due to ankylosing spondylitis, and $10 \%$ and $5 \%$ were being treated due to psoriatic arthritis and juvenile idiopathic arthritis, respectively. The detailed data of the patient population are summarized in Table I. Age distribution was associated with disease. Rheumatoid arthritis was the most common in patients aged 30-59 while ankylosing spondylitis occurred predominantly in patients aged 30-39. Distribution of patients suffering from psoriatic arthritis was similar within the age group 30-59, with some increase in the 50-59 year-old group, and, as expected, juvenile idiopathic arthritis was predominantly seen in patients aged 18-29.

Education of the patients was mostly similar in all subgroups representing various diseases, with some exception for ankylosing spondylitis. This younger group had more patients who were university graduates. Marital status of the patients with specific diseases was related to the average age of the patients. Disorders that are prominent in younger populations have been found to be more common in unmarried or married individuals while those occurring predominantly in older age were more common in divorced or widowed patients (Table I).

Distribution of the specific diseases among inhabitants of villages, small towns and large cities was generally similar (Table II).

\section{Satisfaction}

Various aspects of satisfaction of the patients were estimated. In all subgroups, the effect of the therapy on physical state was very large (Table III). Almost nine out of ten patients (87.8\%) suffering from ankylosing spondylitis considered the influence of biological therapy on his/her physical state as beneficial or very beneficial. Similar but slightly lower results were found in patients with rheumatoid arthritis or psoriatic arthritis. This observation is concordant with physicians' view. The reimbursement plan for patients with ankylosing spondylitis provides an opportunity to administer biological drugs at an earlier stage of the disease than in patients with rheumatoid arthritis. Lack of efficacy or intolerance of two non-steroidal anti-inflammatory drugs is sufficient for initiation of biological therapy. Thus, the slightly higher rate of satisfaction found in patients with ankylosing spondylitis may result from the effect of therapy on physical state when the medication is applied at an earlier stage of the disease as compared to other subgroups of investigated patients.

Sleep quality is known to be disturbed in chronic inflammatory disorders and in rheumatic diseases pain is an additional factor affecting quality of sleep. The data provided in Table III indicate that biological therapy is very beneficial in controlling sleep disturbances in investigated patients. The highest rate of a very beneficial response to biological therapy in patients with ankylosing spondylitis may be related to management of so-called inflammatory back pain, a characteristic feature of the disease causing sleep disturbances in the second half of the night.

Table III summarizes the effect of biological therapy on the financial state of the patients. The obtained results are very similar in all subgroups representing various diseases. Almost half of the patients reported lack of such influence. A similar percentage of patients considered such influence as negative and positive. The financial state of the patients who were not employed and were receiving disablement pension was considered "not applicable". Moreover, most of them were not interested in finding a job because it was possible that the disability benefit would be similar to a salary from the employment and in many regions of the country, and finding a job for some patients might be a significant problem. Of course, such factors as profession and education were critical points in discussing the problem. Additionally, disablement pension is considered as a low 
Table III. Effect of biological therapy on various aspects of patients' life

\begin{tabular}{|c|c|c|c|c|c|}
\hline Aspect of life & All (\%) & $\begin{array}{l}\text { Rheumatoid } \\
\text { arthritis (\%) }\end{array}$ & $\begin{array}{c}\text { Ankylosing } \\
\text { spondylitis (\%) }\end{array}$ & $\begin{array}{l}\text { Psoriatic } \\
\text { arthritis (\%) }\end{array}$ & $\begin{array}{l}\text { Juvenile idiopathic } \\
\text { arthritis (\%) }\end{array}$ \\
\hline \multicolumn{6}{|l|}{ Physical state } \\
\hline Very negative & $13(1.1)$ & $8(1.3)$ & $1(0.2)$ & $3(2.6)$ & $1(1.6)$ \\
\hline Negative & $55(4.5)$ & $35(5.8)$ & $14(3.3)$ & $3(2.6)$ & $3(4.8)$ \\
\hline No effect & $125(10.3)$ & $67(11.1)$ & $37(8.7)$ & 15 (12.8) & $6(9.7)$ \\
\hline Beneficial & $610(50.4)$ & $311(51.3)$ & $218(51.0)$ & 45 (38.5) & $36(58.1)$ \\
\hline Very beneficial & 409 (33.7) & $185(30.5)$ & $157(36.8)$ & $51(43.5)$ & $16(25.8)$ \\
\hline \multicolumn{6}{|l|}{ Sleep quality } \\
\hline Very negative & $12(1.0)$ & $6(1.0)$ & $2(0.5)$ & $2(1.7)$ & $2(3.2)$ \\
\hline Negative & $54(4.5)$ & $35(5.8)$ & $16(3.7)$ & $2(1.7)$ & $1(1.6)$ \\
\hline Lack of effect & $317(26.2)$ & $183(30.2)$ & 68 (15.9) & 35 (29.9) & $31(50.0)$ \\
\hline Beneficial & $503(41.5)$ & $256(42.2)$ & $177(41.5)$ & $45(38.5)$ & $25(40.4)$ \\
\hline Very beneficial & $326(26.8)$ & $126(20.8)$ & $164(38.4)$ & $33(28.2)$ & $3(4.8)$ \\
\hline \multicolumn{6}{|c|}{ Patient's view of the effect of biological therapy on his/her financial situation } \\
\hline Very negative & $12(1.0)$ & $4(0.7)$ & $5(1.2)$ & $2(1.7)$ & $1(1.6)$ \\
\hline Negative & $88(7.3)$ & $50(8.2)$ & $25(5.9)$ & $7(6.0)$ & $6(9.7)$ \\
\hline No influence & $576(47.5)$ & $278(45.9)$ & $207(48.5)$ & $56(47.9)$ & $35(56.5)$ \\
\hline Beneficial & $222(18.3)$ & $95(15.7)$ & $95(22.2)$ & $26(22.2)$ & $6(9.7)$ \\
\hline Very beneficial & $179(14.8)$ & $139(22.9)$ & $30(7.0)$ & $8(6.8)$ & $2(3.2)$ \\
\hline Not applicable & 135 (11.1) & $40(6.6)$ & 65 (15.2) & $18(15.4)$ & $12(19.3)$ \\
\hline \multicolumn{6}{|l|}{ Family life } \\
\hline Very negative & $4(0.3)$ & $1(0.2)$ & $1(0.2)$ & $2(1.7)$ & 0 \\
\hline Negative & $20(1.7)$ & $12(2.0)$ & $5(1.2)$ & $2(1.7)$ & $1(1.6)$ \\
\hline No influence & $303(25.0)$ & $172(28.4)$ & $84(19.7)$ & $23(19.7)$ & $24(38.8)$ \\
\hline Beneficial & 499 (41.2) & $256(42.2)$ & $174(40.7)$ & 48 (41.0) & $21(33.8)$ \\
\hline Very beneficial & 347 (28.6) & 145 (23.9) & $152(35.6)$ & $38(32.5)$ & $12(19.4)$ \\
\hline Not applicable & $39(3.2)$ & $20(3.3)$ & $11(2.6)$ & $4(3.4)$ & $4(6.4)$ \\
\hline \multicolumn{6}{|c|}{ Ability to perform housekeeping work at home } \\
\hline Very negative & $13(1.1)$ & $6(1.0)$ & $2(0.5)$ & $4(3.4)$ & $1(1.6)$ \\
\hline Negative & $43(3.5)$ & $33(5.4)$ & $7(1.6)$ & $1(0.9)$ & $2(3.2)$ \\
\hline No influence & $185(15.3)$ & $98(16.2)$ & $51(11.9)$ & $22(18.7)$ & $14(22.6)$ \\
\hline Beneficial & $556(45.8)$ & $289(47.7)$ & $202(47.3)$ & $43(36.8)$ & $22(35.6)$ \\
\hline Very beneficial & $385(31.8)$ & $164(27.1)$ & $157(36.8)$ & $45(38.5)$ & $19(30.6)$ \\
\hline Not applicable & $30(2.5)$ & $16(2.6)$ & $8(1.9)$ & $2(1.7)$ & $4(6.4)$ \\
\hline
\end{tabular}

but more stable source of income as compared to job position.

The negative effect of the therapy on the financial state of the patients probably resulted from the cost of travel to the rheumatological center. Certain patients who were working during therapy were afraid of disclosing their medical condition to the employer and preferred to take an unpaid day off for the visit to the medication center than a partially paid sick-leave day.
Correlation studies (data not shown) revealed only a trend (not significant) of a more beneficial effect of biological therapy on financial state in patients with a higher education level and those living in big cities than in those who were relatively uneducated and inhabited rural regions.

A beneficial or very beneficial influence of the therapy on family life was reported by the patients (Table III). There was also a substantial group of the patients who 
found no effect of administration of biologics on their family life. There was no significant difference between subgroups of the patients with various diseases. Very similar results were reported relating to the influence of the treatment on ability to perform housekeeping work (Table III). Small groups of the patients responded "not applicable"; it is assumed that they were single persons living without family.

Good quality of life is usually related in part to sexual life. Table IV indicates a beneficial effect of biological therapy on sexual life. The highest positive effect of biological therapy on sexual life was reported in patients with ankylosing spondylitis. This disease, affecting predominantly young males, has a profound influence on sexual life [10-15]. Six of ten patients reported a beneficial effect of the therapy. Additionally, patients with psoriatic arthritis, a disease associated with cutaneous abnormalities, may benefit from biological therapy, and it may result in improvement in their sexual life $[16,17]$.

Other aspects of quality of life are interpersonal relations and leisure time. Both factors are influenced by a number of factors, including ability to move, clear skin in easily visible parts of the body as well as general level of satisfaction. Of course, patients with rheumatic disorders have to abstain from several forms of leisure especially associated with travelling and sport performances, but the predominance of "beneficial" and "very beneficial" answers on those items of the questionnaire are important proof of enhanced satisfaction in the patients. There were no significant differences between patients suffering from any specific disease (Table IV).

Cumulative evaluation of the effect of biological therapy on the patients' life is summarized in Table V. Nine out of ten patients considered the effect of management as beneficial or very beneficial, and there were no differences between groups suffering from various diseases.

\section{Disadvantages of biological therapy}

Travel to the center is a difficulty and impediment for several patients. In general, there are great differences in accessibility of the centers within various parts of the country. This disadvantage is summarized in Table VI. About $40 \%$ of the patients considered it as a disadvantage. There were no differences between groups of the patients with various diseases except those with juvenile idiopathic arthritis. For these patients, travelling to a medical center was a slightly more common impedi-

Table IV. Effect of biological therapy on interpersonal relations, sexual life and leisure time

\begin{tabular}{|c|c|c|c|c|c|}
\hline Aspect of life & All (\%) & $\begin{array}{l}\text { Rheumatoid } \\
\text { arthritis (\%) }\end{array}$ & $\begin{array}{c}\text { Ankylosing } \\
\text { spondylitis (\%) }\end{array}$ & $\begin{array}{l}\text { Psoriatic arthritis } \\
\text { (\%) }\end{array}$ & $\begin{array}{c}\text { Juvenile idiopathic } \\
\text { arthritis (\%) }\end{array}$ \\
\hline \multicolumn{6}{|c|}{ Interpersonal relations } \\
\hline Very negative & $2(0.2)$ & $1(0.2)$ & 0 & $1(0.9)$ & 0 \\
\hline Negative & $23(1.9)$ & $11(1.8)$ & $7(1.6)$ & $3(2.6)$ & $2(3.2)$ \\
\hline No influence & $360(29.6)$ & $198(32.6)$ & $112(26.2)$ & $26(22.2)$ & $24(38.8)$ \\
\hline Beneficial & $481(39.7)$ & $240(39.6)$ & $174(40.7)$ & $44(37.5)$ & $23(37.1)$ \\
\hline Very beneficial & $300(24.8)$ & $127(21.0)$ & $123(28.9)$ & $40(34.2)$ & $10(16.1)$ \\
\hline Not applicable & $46(3.8)$ & $29(4.8)$ & $11(2.6)$ & $3(2.6)$ & $3(4.8)$ \\
\hline \multicolumn{6}{|l|}{ Sexual life } \\
\hline Very negative & $3(0.2)$ & $1(0.2)$ & $1(0.2)$ & $1(0.9)$ & 0 \\
\hline Negative & $44(3.6)$ & $28(4.6)$ & $11(2.6)$ & $4(3.4)$ & $1(1.6)$ \\
\hline No influence & $390(32.2)$ & $206(34.0)$ & $112(26.2)$ & $42(35.9)$ & $30(48.5)$ \\
\hline Beneficial & $406(33.5)$ & $187(30.9)$ & $165(38.7)$ & $44(37.6)$ & $10(16.1)$ \\
\hline Very beneficial & $220(18.2)$ & $87(14.3)$ & $102(23.9)$ & $21(17.9)$ & $10(16.1)$ \\
\hline Not applicable & $149(12.3)$ & $97(16.0)$ & $36(8.4)$ & $5(4.3)$ & $11(17.7)$ \\
\hline \multicolumn{6}{|l|}{ Leisure time } \\
\hline Very negative & $8(0.7)$ & $3(0.5)$ & $3(0.7)$ & $2(1.7)$ & 0 \\
\hline Negative & $58(4.8)$ & $34(5.6)$ & $11(2.6)$ & $8(6.8)$ & $5(8.1)$ \\
\hline No influence & $296(24.4)$ & $184(30.4)$ & $81(18.9)$ & $23(19.7)$ & $8(12.9)$ \\
\hline Beneficial & $492(40.6)$ & $246(40.6)$ & $177(41.5)$ & $41(35.0)$ & $28(45.2)$ \\
\hline Very beneficial & $358(29.5)$ & 139 (22.9) & 155 (36.3) & $43(36.8)$ & $21(33.8)$ \\
\hline
\end{tabular}


Table V. Cumulative patient's evaluation of the effect of biological therapy on his/her life

\begin{tabular}{|lccccc|}
\hline Evaluation & All (\%) & $\begin{array}{c}\text { Rheumatoid } \\
\text { arthritis (\%) }\end{array}$ & $\begin{array}{c}\text { Ankylosing } \\
\text { spondylitis (\%) }\end{array}$ & $\begin{array}{c}\text { Psoriatic arthritis } \\
(\%)\end{array}$ & $\begin{array}{c}\text { Juvenile idiopathic } \\
\text { arthritis (\%) }\end{array}$ \\
\hline Very negative & $4(0.3)$ & $1(0.2)$ & $1(0.2)$ & $2(1.7)$ & 0 \\
\hline Negative & $46(3.8)$ & $30(5.0)$ & $11(2.6)$ & $4(3.4)$ & $1(1.6)$ \\
\hline No influence & $88(7.3)$ & $53(8.7)$ & $19(4.4)$ & $8(6.8)$ & $8(12.8)$ \\
\hline Beneficial & $598(49.3)$ & $303(50.0)$ & $216(50.6)$ & $48(41.0)$ & $31(50.0)$ \\
\hline Very beneficial & $476(39.3)$ & $219(36.1)$ & $180(42.2)$ & $55(47.0)$ & $22(35.6)$ \\
\hline
\end{tabular}

Table VI. Selected disadvantages of biological therapy

\begin{tabular}{|c|c|c|c|c|c|}
\hline Disadvantages & All (\%) & $\begin{array}{l}\text { Rheumatoid } \\
\text { arthritis (\%) }\end{array}$ & $\begin{array}{c}\text { Ankylosing } \\
\text { spondylitis (\%) }\end{array}$ & $\begin{array}{c}\text { Psoriatic } \\
\text { arthritis (\%) }\end{array}$ & $\begin{array}{l}\text { Juvenile idiopathic } \\
\text { arthritis (\%) }\end{array}$ \\
\hline \multicolumn{6}{|l|}{ Travel to the medical center } \\
\hline Great impediment & $103(8.5)$ & $47(7.8)$ & $36(8.4)$ & $9(7.7)$ & $11(17.7)$ \\
\hline Impediment & $395(32.6)$ & $199(32.8)$ & $135(31.6)$ & $39(33.3)$ & $22(35.5)$ \\
\hline Unimportant & $670(55.3)$ & $328(54.1)$ & $244(57.2)$ & $69(59.0)$ & $29(46.8)$ \\
\hline I do not know & $44(3.6)$ & $32(5.3)$ & $12(2.8)$ & $0(0.0)$ & $0(0.0)$ \\
\hline \multicolumn{6}{|c|}{ Blood sampling during regular check-up visits related to biological therapy } \\
\hline Great impediment & $21(1.7)$ & $8(1.3)$ & $4(0.9)$ & $3(2.6)$ & $6(9.7)$ \\
\hline Impediment & $134(11.1)$ & $69(11.4)$ & $46(10.8)$ & $11(9.4)$ & $8(12.9)$ \\
\hline Unimportant & $1057(87.2)$ & $529(87.3)$ & $377(88.3)$ & $103(88.0)$ & $48(77.4)$ \\
\hline \multicolumn{6}{|c|}{ Laboratory and imaging tests required to be started on biological therapy } \\
\hline Significant inconvenience & $40(3.3)$ & $17(2.8)$ & $19(4.4)$ & $3(2.6)$ & $1(1.6)$ \\
\hline Inconvenience & $213(17.6)$ & $88(14.5)$ & $87(20.4)$ & $30(25.6)$ & $8(12.9)$ \\
\hline Unimportant issue & $811(66.9)$ & $409(67.5)$ & $276(64.7)$ & $77(65.8)$ & $49(79.1)$ \\
\hline I do not know & $148(12.2)$ & $92(15.2)$ & $45(10.5)$ & $7(6.0)$ & $4(6.4)$ \\
\hline \multicolumn{6}{|c|}{ Waiting period for biological therapy } \\
\hline Significant inconvenience & $177(14.6)$ & $79(13.0)$ & $70(16.4)$ & $18(15.4)$ & $10(16.1)$ \\
\hline Inconvenience & $336(27.7)$ & $145(23.9)$ & $133(31.1)$ & $44(37.5)$ & $14(22.6)$ \\
\hline Unimportant issue & $525(43.3)$ & $266(44.0)$ & $184(43.1)$ & $43(36.8)$ & $32(46.2)$ \\
\hline I do not know & $174(14.4)$ & $116(19.1)$ & $40(9.4)$ & $12(10.3)$ & $6(9.7)$ \\
\hline \multicolumn{6}{|l|}{ Way of drug administration } \\
\hline Very negative & $3(0.3)$ & $3(0.5)$ & 0 & 0 & 0 \\
\hline Negative & $84(6.9)$ & $39(6.4)$ & $25(5.9)$ & $8(6.8)$ & $8(12.9)$ \\
\hline No influence & 993 (81.9) & 463 (76.4) & $363(85.0)$ & $103(88.0)$ & $50(80.6)$ \\
\hline I do not know & $132(10.9)$ & 101 (16.7) & $39(9.1)$ & $6(5.2)$ & $4(6.5)$ \\
\hline
\end{tabular}

ment than for those with other disorders requiring biological therapy.

Blood sampling was found to be a minor disadvantage in most of the patients. More than four-fifths of all of them did not consider blood sampling as a problem. The only group of patients for whom sampling was some problem were those suffering from juvenile idiopathic arthritis, although differences between the groups were rather small. It is possible that memories of blood sam- pling from their childhood affected their estimation of this phenomenon (Table VI).

Laboratory and imaging tests were considered as an inconvenience by a rather a small part of the patients. In contrast, the waiting period for biological therapy is considered as an important issue by about $40 \%$ of the patients (Table VI).

About four-fifths of all patients accepted the way of administration of biological drugs (Table VI). The high- 
est relative rate of the responders "without influence" was in the patients with psoriatic arthritis or ankylosing spondylitis. There was a relatively high rate of patients with rheumatoid arthritis who responded "I do not know". It may indicate that the parenteral way of administration is a generally accepted way of introduction of active medicines into the body.

\section{Discussion}

It is well known that biological therapy has a profound beneficial effect on quality of life of patients with inflammatory rheumatic disorders. The problem of satisfaction or discontent of the patients in reference to administration of biological therapy is more complex and is affected by a number of factors. The factors are of various nature, and include psychological, social and economic factors as well as factors related to culture and tradition $[10,12]$. Most of the factors are specific for the country or its region, including such factors as education, cultural traditions, economic situation and legislative regulations. Thus, these factors affecting satisfaction of patients are different from the factors affecting results of the clinical trials that are evaluating clinical efficacy of biological medication only, and the factors are specific for various groups of the patients.

The present study is according to our knowledge the first such analysis in Poland. The study revealed a relatively beneficial effect of treatment with biologics seen as a high level of satisfaction. The differences between the subgroups of patients with various disorders were shown to be rather minor. Some of them however seem to be of interest. The beneficial effect of biological therapy on cutaneous and articular involvement in patients suffering from psoriatic arthritis probably explains the slightly higher satisfaction of those patients with medication. It is concordant with other studies indicating a depressive effect of skin manifestation of the disease [18-21]. Younger age of the patients with ankylosing spondylitis and administration of biologics in an earlier stage of the disease can explain the beneficial effect of medication on the sexual life of the patients [13-16]. In contrast, patients with a long-lasting disease and several chronic malformations or functional alterations were less satisfied with the biological therapy. It applied mostly to adult patients with juvenile idiopathic arthritis. It should also be underlined that during the study the patients did not find a beneficial effect of medication on their financial situation.

The obtained results are comparable to single reports on selected aspects of patients' satisfaction. Impaired social functioning and leisure activities were reported in patients with ankylosing spondylitis by van Genderen et al. [13]. They suggested the role of support from other individuals in amelioration of such impairments. Some studies reported that many of the patients with ankylosing spondylitis are afraid of malfunctioning within various areas, including professional activity, family life and social functioning $[12,17]$. Some studies indicate a profound negative impact of ankylosing spondylitis on sexual life, especially detectable in male patients [1315]. This finding is in agreement with our observation.

$\mathrm{Ku}$ et al. [11] investigated factors influencing the level of satisfaction of patients with chronic rheumatic diseases and found that the majority of factors are unrelated to the physician or the skills of that physician. This finding is also concordant with our finding; however, knowledge of the nature of the factors affecting the satisfaction level of the patients seems to be important and despite the conclusion of Ku et al. [11] it is possible that the physician has some ability to improve the patient satisfaction.

\section{Conclusions}

The present study indicates the complexity of the problem of patient satisfaction and discontent during biological treatment and suggests the need for further investigations focused on specific aspects of the problem. Satisfaction, especially in chronic diseases, has an impact on patients' adherence to medication. Thus there is a need to maximize the satisfaction, and of course, to measure the patients' satisfaction in the process of medical care.

The authors declare no conflict of interest.

\section{References}

1. Smolen JS, Landewé R, Bijlsma J, et al. EULAR recommendations for the management of rheumatoid arthritis with synthetic and biological disease-modifying antirheumatic drugs: 2016 update. Ann Rheum Dis 2017; 76: 960-977.

2. Nam JL, Takase-Minegishi K, Ramiro S, et al. Efficacy of biological disease-modifying antirheumatic drugs: a systematic literature review informing the 2016 update of the EULAR recommendations for the management of rheumatoid arthritis. Ann Rheum Dis 2017; 76: 1113-1136.

3. Ramiro S, Sepriano A, Chatzidionysiou K, et al. Safety of synthetic and biological DMARDs: a systematic literature review informing the 2016 update of the EULAR recommendations for management of rheumatoid arthritis. Ann Rheum Dis 2017; 76: 1101-1136.

4. Jeka S (ed.). 10 lat leczenia biologicznego chorób reumatycznych w Polsce. Termedia, Poznań 2017.

5. Guła Z, Stec M, Rutkowska-Zapała M, et al. The absolute number of circulating nonclassical (CD14+CD16++) monocytes negatively correlates with DAS28 and swollen joint count in 
patients with peripheral spondyloarthritis. Pol Arch Intern Med 2017; 127: 846-853.

6. Murray-Brown W, Wechalekar MD, Smith M. PD-1+ T cells contribute differently to the pathogenesis of rheumatoid arthritis and psoriatic arthritis. Pol Arch Intern Med 2017; 127: 813814.

7. Bartosińska J, Zakrzewska E, Król A, et al. Differential expression of programmed death 1 (PD-1) on CD4+ and CD8+ T cells in rheumatoid arthritis and psoriatic arthritis. Pol Arch Intern Med 2017; 127: 815-822.

8. Przepiera-Będzak H, Fischer K, Brzosko M. Serum VEGF, EGF, basic FGF, and acidic FGF levels and their association with disease activity and extra-articular symptoms in ankylosing spondylitis. Pol Arch Med Wewn 2016; 126: 290-292.

9. Uthman I, Noureldine MH, Arayssi T, et al. How to treat ankylosing spondylitis and nonradiographic axial spondyloarthritis. Key practical message from the 2015 American College of Rheumatology recommendations. Pol Arch Med Wewn 2016; 126; 254-261.

10. Kucharz EK. Reumatoidalne zapalenie stawów. [In:] Wielka Interna - Reumatologia. Puszczewicz MJ (ed.). 2nd ed. Medical Tribune, Warszawa 2016: 79-951.

11. Ku JH, Danve A, Pang H, et al. Determinants of patient satisfaction in an academic rheumatology practice. J Clin Rheumatol 2015; 21: 256-262.

12. Kucharz EJ, Kotulska A, Kopeć-Mędrek M, et al. Opinion of patients with ankylosing spondylitis on risk factors impairing their quality of life. Rheumatol Int 2013; 33: 2899-2901.

13. Van Genderen S, Plasqui G, van der Heijde D, et al. Social role participation and satisfaction with life: a study among pa- tients with ankylosing spondylitis and population controls. Arthritis Care Res (Hoboken) 2018; 70: 600-607.

14. Fan D, Liu L, Ding N, et al. Male sexual dysfunction and ankylosing spondylitis: a systematic review and metaanalysis. J Rheumatol 2015; 42: 252-257.

15. Liu YF, Dong H, Chen Z, et al. Impact of ankylosing spondylitis on sexual function: a systemic review and meta-analysis. Exp Ther Med 2015; 9: 1501-1507.

16. Dhakad U, Singh BP, Das SK, et al. Sexual disfunctions and lower urinary tract symptoms in ankylosing spondylitis. Int J Rheum Dis 2015; 18: 866-872.

17. Kucharz EJ. Reumatoseksuologia: wprowadzenie do problematyki interdyscyplinarnej. Reumatologia 2010; 48: 155158.

18. Boonen A, Boone C, Albert A, et al. Understanding limitations in at-work productivity in patients with active ankylosing spondylitis: the role of work-related contextual factors. J Rheumatol 2015; 42: 93-100.

19. Urruticoechea-Arana A, Serra Torres M, Hergueta Diaz M, et al. Experience and satisfaction with a multidisciplinary care unit for patients with Psoriasis and psoriatic arthritis. Reumatol Clin 2017; pii: S1699-258X(17)30183-3 [Epub ahead of print].

20. González CM, Carmona L, de Toro J, et al. Perceptions of patients with rheumatic diseases on the impact on daily life and satisfaction with their medications: RHEU-LIFE, a survey to patients treated with subcutaneous biological products. Patient Prefer Adherence 2017; 11: 1243-1252.

21. Husni ME, Merola JF, Davin S. The psychosocial burden of psoriatic arthritis. Semin Arthritis Rheum 2017; 47: 351-360. 